\section{Periodontal outcomes and social, racial and gender inequalities in Brazil: a systematic review of the literature between 1999 and 2008}

\author{
Condições periodontais e desigualdades sociais, \\ raciais e de gênero no Brasil: revisão sistemática \\ da literatura do período de 1999 a 2008
}

1 Departamento de Saúde
Pública, Universidade
Federal de Santa Catarina,
Florianópolis, Brasil.
2 Faculdade de Saúde
Pública, Universidade de São
Paulo, São Paulo, Brasil.
Correspondence
J. L. Bastos
Programação de Pós-
graduação em Saúde Coletiva,
Departamento de Saúde
Pública, Universidade Federal
de Santa Catarina.
Campus Universitário Reitor
João David Ferreira Lima,
Florianópolis, SC 88040-970,
Brasil.
joao.luiz.epi@gmail.com

Abstract

The objective of this study was to review the Brazilian epidemiologic literature on periodontal outcomes and socio-demographic factors, assessing bibliographic and methodological characteristics of this scientific production, as well as the consistency and statistical significance of the examined associations. A systematic review was carried out in six bibliographic sources. The review was limited to the period between 1999 and 2008, without any other type of restriction. Among the 410 papers identified, 29 were included in the review. An increasing number of articles, specifically in the last four years of study, was observed. However, there is a concentration of studies in the South and Southeast regions of Brazil, and many of them are not closely connected to theoretical formulations in the field. In spite of these shortcomings, the review findings corroborate the idea that poor socioeconomic conditions are associated with periodontal outcomes, as demonstrated primarily by income and schooling indicators.

Periodontal Diseases; Health Inequalities; Review
João Luiz Bastos 1 Antonio Fernando Boing 1 Karen Glazer Peres 1 José Leopoldo Ferreira Antunes 2 Marco Aurélio Peres 1

\section{Introduction}

Globally, signs of gingival inflammation (gingivitis) are observed in the majority of the population, while, among adults, the initial stages of periodontal disease (periodontitis) are highly prevalent 1 . It is estimated that severe periodontitis, which may result in tooth loss, affects between $5 \%$ and $15 \%$ of most populations worldwide 1 . Aggressive periodontitis, a severe condition affecting individuals during puberty that leads to premature tooth loss, affects around $2 \%$ of youths 1 . In addition, as periodontal diseases cause an impact on individuals and communities 2 , and the costs involved in the treatment of the most severe cases are high, these are considered one of the main public health concerns in the oral health field 1 .

Periodontal diseases are associated with negative self-rated oral health, even when other dental outcomes and socioeconomic conditions are taken into account 2 . Contrary to what happens with dental caries, the prevalence of periodontal diseases may increase in the future as a consequence of improvements in life expectancy and the growth of populations, which will present an increased number of people with a higher number of natural teeth 3 . This picture is particularly relevant in countries, such as Brazil, which experience a rapid ageing process.

The accumulation of supra- and specific subgingival microflora of dental plaque biofilms are 
the main causes of both destructive periodontal disease and gingivitis 4 , mainly due to poor oral hygiene; diabetes mellitus, and tobacco smoking have also been identified as important risk factors for the development of these inflammatory processes 5 . In contrast, the role of other potential risk factors, such as the ageing process, needs to be clarified in future investigations 5 .

In spite of insufficient tooth-brushing and smoking being more prevalent among population subgroups that are socially and economically underprivileged 6 , most epidemiological and clinical research investigating the causes of periodontal diseases focus on their biological aspects, with a recent emphasis on genetic characteristics of individuals and on the morphology and microbial aspects of periodontal sites 7 .

Research carried out in the USA indicated that periodontal diseases are more prevalent among people who classify themselves as black, and in those with low levels of schooling and income. Moreover, these inequalities have persisted over the years 8,9 . On the other hand, the authors of a systematic review 10 addressing socioeconomic inequalities in the distribution of periodontal diseases emphasized that these disparities were inconsistent, particularly in studies with a prospective longitudinal or case-control design, in which smoking status was included as a covariate in the analyses. Based on these results, they argued that socioeconomic variables appeared to be of less importance than smoking for periodontal disease etiology. Nevertheless, this synthesis included only five studies carried out in low-income countries out of the 47 reviewed, with no investigations originating in Brazil. Furthermore PubMed was the only data source used by these authors, and the period covered ended in 2004.

Reviews assessing social inequalities in the occurrence of periodontal outcomes are absent in Brazil. This causes some concern, because socioeconomic, cultural and environmental conditions are considered the most distal determinants of diseases 11. Latin America and SubSaharan Africa are the regions with the highest levels of income inequality in the world ${ }^{12}$. Despite a decrease in income inequality in Latin America in 2000, the situation is still dramatic. Brazil, for example, has the fifth most unequal income distribution in this already unequal part of the world 13.

Although social inequalities are more pronounced in oral health outcomes than in any other health outcome 14, there is a lack of summarization and systematization of knowledge of this field in Brazil. In particular, no previous literature review attempted to answer the following two re- search questions: "Are there socioeconomic and demographic inequalities in the occurrence of periodontal outcomes in Brazil?" "Are studies addressing such inequalities devised to test specific hypotheses, derived from consistent theories on the subject matter?" The answers to these questions need to be made available to policy makers in order to implement public policies aimed at the reduction of inequalities in oral health. Therefore, the aim of this study was to identify and to analyze research carried out in Brazil, investigating the association between periodontal outcomes and socioeconomic conditions, race, ethnicity or skin color and sex/gender.

\section{Methods}

\section{Search strategy and bibliographic sources}

This literature review was based on the following six electronic bibliographic data sources: LILACS (Latin American and Caribbean Literature in Health Sciences), BBO (Brazilian Dentistry Library), MEDLINE via PubMed, SciELO (Scientific Electronic Library on line), Scopus and Web of Science. Each data source was checked for availability and usage of controlled vocabulary for indexation through the use of hierarchically defined and periodically updated thesauruses. This strategy enabled, in four out of six data sources, the construction of specific search queries by taking into consideration the terms of interest and the hierarchical structures in which these were found. For the data sources in which a thesaurus was unavailable, the search was performed using free search terms, based on the controlled vocabulary already used and on the previous experience of the authors of this review. The literature search was conducted within a limited time frame, from January 1999 to December 2008 without any type of restriction.

When possible, search queries followed a previously planned structure. The first group of terms would define the outcomes of interest, in this case, all expressions possibly related to periodontal outcomes. Another term would define the publication's country of origin - Brazil. Finally, the last group of terms would cover the socioeconomic and demographic conditions of interest: Brazilian region, place of residence (rural or urban), sex/gender, race, ethnicity or skin color, and social position of investigated groups and individuals. For instance, the search query used in PubMed included the following controlled and free terms: periodontal diseases, Brazil, population characteristics, state government, geographic locations, skin pigmentation, race relations, race, 
minority groups, sex, and sex factors. The complete list of search queries used in this review is available from the authors upon request.

In this review we approached all possible periodontal outcomes, instead of focusing on specific periodontal pathological conditions, including mild and severe conditions, such as gingivitis and clinical attachment loss or periodontitis. This is justified due to the scarcity of Brazilian studies in the field, and because the controlled term periodontal disease automatically covers, for example, in PubMed any pathological process involving the periodontum, including less severe conditions such as gingivitis and gingival recession.

\section{Identification of studies and inclusion criteria}

The following criteria were adopted for the selection of potentially eligible papers: (a) the studies should be epidemiologic, without any restriction on design, and should address any type of periodontal outcome; (b) the subjects investigated should live in Brazil; and (c) the papers should examine the relationship between the socioeconomic and demographic conditions and the outcome. Studies included were those with an explicit interest in the investigation of social determinants of periodontal conditions, as well as investigations with a different objective, but which also empirically examined some or all of the relations of interest for this review.

Search results in each of the data sources investigated were stored and managed with EndNote, version 8 for Windows (Thomson Reuters, http://www.endnote.com, United States). The first and the second authors of this review read the article titles independently and, when necessary, the abstracts of the selected articles in order to exclude papers which did not meet the inclusion criteria. When the paper was considered relevant for the review but its abstract was unavailable, the full text of the article was obtained and then evaluated for inclusion criteria. Disagreements between the two reviewers were sorted out by consensus by reading the full article for a final decision to be made.

In addition to the identification of the papers in the mentioned data sources, all articles referred to in the searched papers were checked to determine whether they met the inclusion criteria. Disagreements between the two reviewers were discussed according to the above mentioned criteria and refereed by a third author.

\section{Data extraction}

All papers that were included had their data extracted independently by the same two authors, using a spreadsheet pre-tested in a sample of articles. The information that was extracted was checked by the authors and, when necessary, a new consultation was performed by reading the full texts again. We did not estimate agreement measures from the extracted data between the authors. Data were typed independently by a research assistant in EpiData, version 3.1 for Windows (Epidata Association, Odense, Denmark), which automatically checked data consistency and amplitude.

For each article included, information referring to the journal, year of publication, first author institutional affiliation, Brazilian region in which the study was conducted, minimum and maximum sample age and sample size (taking into account drop-out or exclusion explained by the article's authors) were all extracted for each article of this review. In addition, it was verified if the study evaluated the association between periodontal outcomes and socioeconomic and demographic characteristics, adopting an explicit theoretical framework. The type of epidemiological design (cross-sectional, ecological, case-control, cohort, or other) and the sampling scheme (self-weighted, complex, convenience, census, or other) were also described.

With regard to periodontal outcomes, we collected indexes and criteria adopted in the evaluation of periodontal conditions. We also detailed the socioeconomic and demographic variables collected, the associations that were statistically significant $(\mathrm{p}<0.05)$ with the studied outcomes, and the direction or shape of these associations. Outcomes encompassed gingivitis, periodontitis, and other periodontal conditions, defined according to criteria adopted by the original authors of the reviewed studies. The direction or shape of association was classified as follows: positive, negative, U shaped (intermediate exposure categories of a variable with 3 or more categories showing lower outcome frequencies than categories from higher and lower exposure), and not described. When sex/gender and race, ethnicity or skin color were taken into account, the direction of association was classified as higher in males, higher in females, higher in self-reported whites and so on. All directions and shapes of association were described for all cross tabulations and not only for those which were statistically significant. This allowed for the estimation of the proportion of statistically significant associations among all those evaluated in the original studies. 


\section{Quality assessment}

This review was set up to evaluate the methodological quality of the included investigations with the Downs \& Black's 15 checklist, as this instrument has been previously used with observational studies 16. However, this checklist performed poorly in a sample of three studies fitting the eligibility criteria. Thus, information on the methodological characteristics of the studies were collected only with regard to the following aspects: the presentation of outcome reliability measures, parameters for the calculation of sample sizes, eligibility criteria for study participants, and description of data quality control strategies.

\section{Statistical analysis}

Analysis included the description of the above mentioned characteristics of articles by means of relative and absolute frequencies as well as by contingency tables. All analyses were performed using the Stata, version 9 software (Stata Corp., College Station, USA).

\section{Results}

The bibliographic characteristics of 29 articles $17,18,19,20,21,22,23,24,25,26,27,28,29,30,31,32,33,34,35,36,37,38$, $39,40,41,42,43,44,45$ included in this review (see Figure 1 with the review flow chart) are shown in Table 1. The period between 2005 and 2008 accounts for more than half of all scientific production in the period studied. A noticeable concentration of articles originated from the South and Southeast regions of Brazil; almost one quarter of all production came from the São Paulo University (Universidade de São Paulo). The articles were published in 14 journals; three international journals had the highest number of published articles. The population studied was relatively young, and a wide variation in the sample sizes was observed. Almost all studies $(\mathrm{N}=28 ; 96.6 \%)$ adopted a cross-sectional design, using a complex sampling design.

The participants' eligibility criteria, the detailed explanation about the outcome as well as the presentation of their reliability measures were found in most of the studies reviewed. On the other hand, the theoretical framework used to explain the relationship between the outcome and the socioeconomic and demographic exposures was rarely clarified. Few studies presented the parameters that guided the sample size calculation and very few described strategies to assess data quality control (Table 2).
Table 3 displays the wide variability of periodontal outcomes and socioeconomic and demographic variables tested in the original studies. Different classification criteria of periodontal outcomes were used, with a high concentration in one main index, the Community Periodontal Index (CPI). The most common inequality indicators were sex/gender, schooling, income and race, ethnicity or skin color.

Table 4 summarizes the direction or shape of association between studied outcomes and socioeconomic and demographic indicators, as well as their statistical significance. Geographical region and place of residence were excluded from this analysis because their associations with the periodontal outcomes were only tested four times. The most tested socioeconomic and demographic variable was sex/gender followed by income, race, ethnicity or skin color, schooling and by one variable which combined different indicators of socioeconomic position. Periodontal outcomes were relatively more frequent among males, being statistically significant in almost half of these associations. Income and schooling were negatively associated with periodontal outcomes in nearly all of the cross-tabulations; among them, a third and two-thirds were statistically significant, respectively. Those self-reported as non-black showed higher frequencies of periodontal outcomes in half of the examined associations but a statistically significant association was found only in two. In all nine situations where the combined socioeconomic position indicator was used, it was negatively correlated with periodontal outcomes, but these associations were statistically significant in only half of the cases.

\section{Discussion}

The Brazilian scientific literature addressing social determinants of periodontal outcomes is quantitatively limited, but an increase in its production has been identified over the last few years. However, the increase of this literature does not seem to be closely connected to theoretical formulations in the field, and the papers reviewed here do not seem to answer relevant or specific research questions. On the other hand, this picture represents the current stage of Brazilian research in general and oral health specifically; an expressive increase in the number of published papers is observed $46,47,48$ but its quality needs to be improved.

In spite of the aforementioned limitations, the review findings allow us to corroborate the idea that poor socioeconomic indicators are associated with periodontal outcomes, contrary 


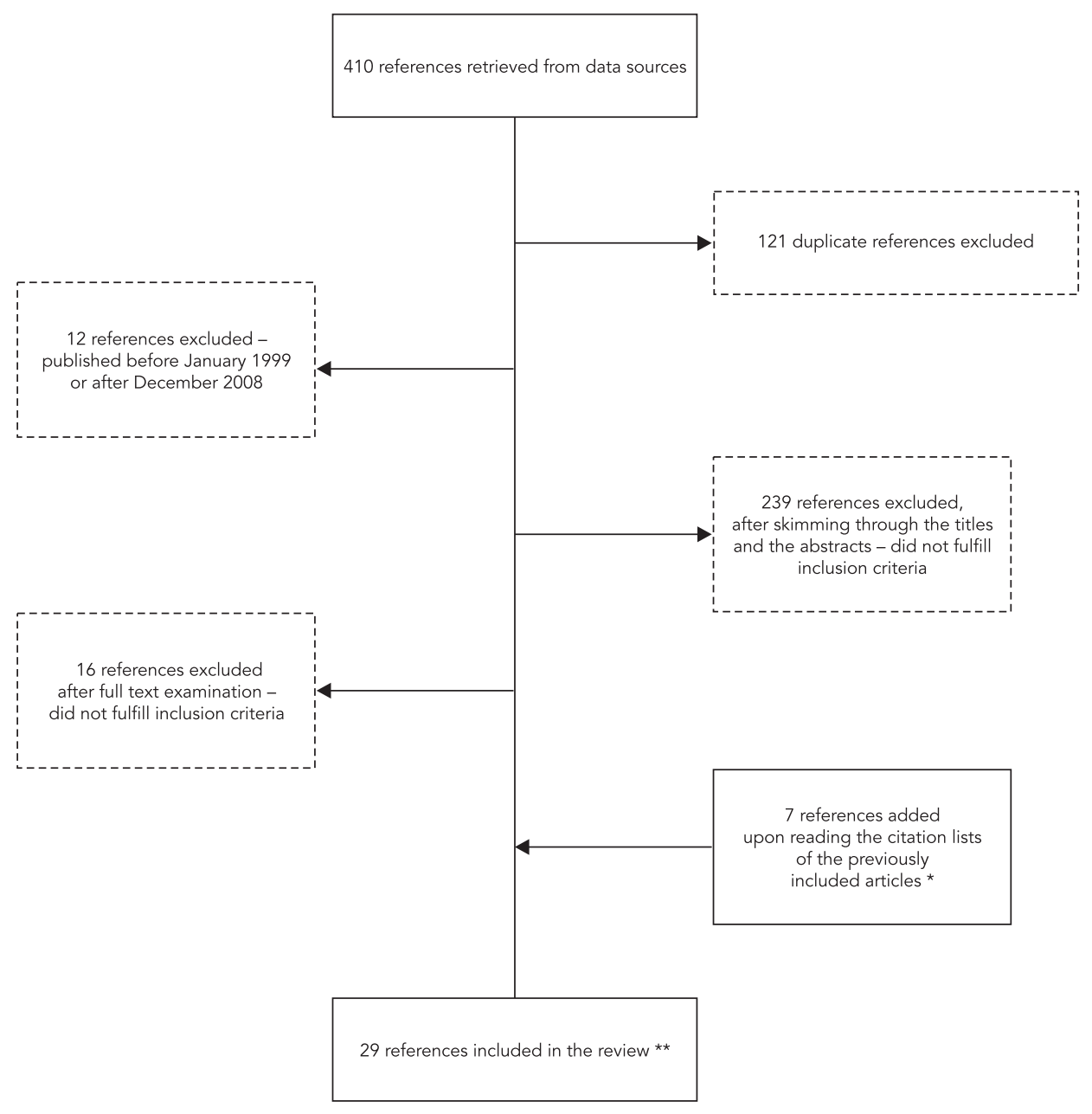

* References: $18,19,20,21,22,36,53$;

** References: $17,18,19,20,21,22,23,24,25,26,27,28,29,30,31,32,33,34,35,36,37,38,39,40,41,42,43,44,45$.

to the main argument pointed out previously in the literature 10 . Klinge \& Norlund 10 suggest that the statistically significant and negative association between socioeconomic conditions and periodontal disease is questionable, because the studies that come to this conclusion have been, in their majority, cross-sectional and most did not adjust this association for smoking in their analysis. Both arguments are doubtful. Firstly, the main limitation of cross-sectional studies is the difficulty in establishing temporal relationships, which makes the assessment of causality even more complex. However, when social determinants in oral health are the focus of the in- vestigation, it is less probable that this kind of difficulty arises, given that many of the exposures of interest are quite stable and/or occur early in the life course. Care must be taken, though, since this last assertion may not always apply to the wide variety of inequality indicators used in the reviewed studies. Secondly, tobacco smoking is an intervenient factor of the relationship between socioeconomic indicators and periodontal outcomes, and as such, it is not recommended to be controlled for when statistical analysis is performed 49 .

A concentration of the reviewed research in the South and Southeast regions of the country 
Distribution of studies included, according to bibliographic characteristics, study sample size and participants' age. Brazil, 1999-2008.

\begin{tabular}{|c|c|c|}
\hline Characteristic & $\mathrm{n}$ & $\%$ \\
\hline \multicolumn{3}{|l|}{ Year of publication } \\
\hline $1999-2000$ & 2 & 6.9 \\
\hline $2001-2002$ & 5 & 17.2 \\
\hline $2003-2004$ & 6 & 20.7 \\
\hline $2005-2006$ & 7 & 24.1 \\
\hline $2007-2008$ & 9 & 31.0 \\
\hline \multicolumn{3}{|l|}{ Brazilian region } \\
\hline Northeast & 3 & 10.3 \\
\hline North & 1 & 3.4 \\
\hline Southeast & 11 & 37.9 \\
\hline South & 13 & 44.8 \\
\hline Does not apply (nationally representative study) & 1 & 3.4 \\
\hline \multicolumn{3}{|l|}{ First author's institution } \\
\hline USP & 6 & 20.7 \\
\hline Temple University, United States of America & 5 & 17.2 \\
\hline UFSC & 2 & 6.9 \\
\hline UNICAMP & 2 & 6.9 \\
\hline Other* & 14 & 48.3 \\
\hline \multicolumn{3}{|l|}{ Journal } \\
\hline Journal of Clinical Periodontology & 7 & 24.1 \\
\hline Journal of Periodontology & 6 & 20.7 \\
\hline Oral Health \& Preventive Dentistry & 3 & 10.3 \\
\hline Revista de Saúde Pública & 3 & 10.3 \\
\hline Pesquisa Odontológica Brasileira & 2 & 6.9 \\
\hline Other ${ }^{\star \star}$ & 8 & 27.6 \\
\hline \multicolumn{3}{|l|}{ Sample size } \\
\hline Minimum-maximum & $96-11,342$ & \\
\hline Mean sample size (standard deviation) & $1,085(2,230)$ & \\
\hline Median sample size & 518 & \\
\hline \multicolumn{3}{|l|}{ Participants' age } \\
\hline Minimum age [mean (standard deviation)] & $16(10)$ & \\
\hline Minimum age [median] & 14 & \\
\hline Maximum age [mean (standard deviation)] & $42(36)$ & \\
\hline Maximum age [median] & 22 & \\
\hline
\end{tabular}

* Remaining institutions published only one article each;

** Remaining journals $(n=8)$ published only one article each.

UFSC: Santa Catarina Federal University; UNICAMP: Campinas State University; USP: São Paulo University.

and the supremacy of cross-sectional studies follow the general trends for overall scientific production in Brazilian health sciences. It is desirable that research activities be developed in other Brazilian regions, especially in those where social inequalities are preeminent. The predominance of cross-sectional studies in our review was expected and it is understandable, because this epidemiological design is practical and less expensive in comparison with other kinds of studies.

The majority of the scientific production reviewed was published in international journals. From a scientific point of view, this may reflects the broad international interest in inequalities in periodontal diseases. However, this makes it difficult to ensure that these papers are widely available, especially for Brazilian 


\section{Table 2}

Distribution of studies included, according to methodological characteristics. Brazil, 1999-2008.

\begin{tabular}{lcc}
\hline Characteristic & $\mathrm{n}$ & $\%$ \\
\hline Study design & & \\
$\quad$ Cross-sectional & 28 & 96.6 \\
Case-control & 1 & 3.4 \\
$\quad$ Sampling process & 2 & 6.9 \\
Simple casual sampling & 15 & 51.7 \\
$\quad$ Complex & 7 & 24.1 \\
Convenience sampling & 4 & 13.8 \\
Census & 1 & 3.4 \\
$\quad$ Not described & 5 & 17.2 \\
Clarification of the theoretical framework underlying relationships between exposure and outcome e & 26 & 89.7 \\
Description of eligibility criteria for study participants & 12 & 41.4 \\
Presentation of parameters for sample size calculation & 29 & 100.0 \\
Clear definition of outcomes & 22 & 75.9 \\
Presentation of outcome reliability scores & 3 & 10.3 \\
Report of data quality control strategies & 22 \\
\hline
\end{tabular}

Table 3

Reviewed studies, according to their characteristics. Brazil, 1999-2008.

\begin{tabular}{|c|c|c|c|c|c|c|c|}
\hline First author's surname & $\begin{array}{l}\text { Publication } \\
\text { year }\end{array}$ & $\begin{array}{l}\text { Minimum } \\
\text { age }\end{array}$ & $\begin{array}{l}\text { Maximum } \\
\text { age }\end{array}$ & $\begin{array}{l}\text { Sample } \\
\text { size }\end{array}$ & $\begin{array}{l}\text { Study } \\
\text { design }\end{array}$ & $\begin{array}{l}\text { Outcome } \\
\text { assessment }\end{array}$ & $\begin{array}{l}\text { Inequality } \\
\text { indicators * }\end{array}$ \\
\hline Antunes et al. 17 & 2008 & 15 & 19 & 1,799 & $\begin{array}{l}\text { Cross- } \\
\text { sectional }\end{array}$ & $\begin{array}{c}\mathrm{CPI}-\mathrm{CPI}=1 \text { in } 1+ \\
\text { sextants, } \mathrm{CPI}=2 \text { in } 1+ \\
\text { sextants }\end{array}$ & $\begin{array}{l}\text { Color/race, household } \\
\text { crowding, municipal } \\
\text { human development } \\
\text { index, place of residence, } \\
\text { school retard, sex }\end{array}$ \\
\hline Cortellazzi et al. 28 & 2008 & 5 & 5 & 728 & $\begin{array}{l}\text { Cross- } \\
\text { sectional }\end{array}$ & $\begin{array}{c}3+\text { teeth with gingival } \\
\text { bleeding }\end{array}$ & $\begin{array}{l}\text { Car ownership, household } \\
\text { crowding, household } \\
\text { ownership, income, } \\
\text { parental schooling, sex, } \\
\text { type of school }\end{array}$ \\
\hline Coelho et al. 26 & 2008 & 18 & 85 & 505 & $\begin{array}{l}\text { Cross- } \\
\text { sectional }\end{array}$ & $\begin{array}{l}\mathrm{CPI} \text { - gingival bleeding, } \\
\text { calculus, } 4-5 \mathrm{~mm} \text { pockets } \\
\text { and } 6+\mathrm{mm} \text { pockets }\end{array}$ & $\begin{array}{c}\text { Schooling, sex, } \\
\text { socioeconomic position }\end{array}$ \\
\hline Corraini et al. 27 & 2008 & 12 & $\begin{array}{c}\text { Not } \\
\text { declared }\end{array}$ & 195 & $\begin{array}{l}\text { Cross- } \\
\text { sectional }\end{array}$ & $\begin{array}{l}\% \text { of teeth with probing } \\
\text { depth of } 4+\mathrm{mm} \text { or } 6+\mathrm{mm}\end{array}$ & Illiteracy, income, sex \\
\hline Corraini et al. 25 & 2008 & 12 & $\begin{array}{c}\text { Not } \\
\text { declared }\end{array}$ & 195 & $\begin{array}{l}\text { Cross- } \\
\text { sectional }\end{array}$ & $\begin{array}{l}1+\text { sites with loss of } \\
\text { attachment of } 3+\mathrm{mm} \text { and } \\
7+\mathrm{mm}\end{array}$ & $\begin{array}{l}\text { Illiteracy, income, } \\
\text { schooling, sex }\end{array}$ \\
\hline Peres et al. 39 & 2007 & 35 & 44 & 11,342 & $\begin{array}{l}\text { Cross- } \\
\text { sectional }\end{array}$ & $\begin{array}{l}1+\text { teeth with loss of } \\
\text { attachment loss of } 3+\mathrm{mm} \\
\text { or pocket }\end{array}$ & $\begin{array}{l}\text { Color/race, income, } \\
\text { schooling, sex }\end{array}$ \\
\hline
\end{tabular}

(continues) 
Table 3 (continued)

\begin{tabular}{|c|c|c|c|c|c|c|c|}
\hline First author's surname & $\begin{array}{l}\text { Publication } \\
\text { year }\end{array}$ & $\begin{array}{l}\text { Minimum } \\
\text { age }\end{array}$ & $\begin{array}{l}\text { Maximum } \\
\text { age }\end{array}$ & $\begin{array}{l}\text { Sample } \\
\text { size }\end{array}$ & $\begin{array}{l}\text { Study } \\
\text { design }\end{array}$ & $\begin{array}{l}\text { Outcome } \\
\text { assessment }\end{array}$ & $\begin{array}{l}\text { Inequality } \\
\text { indicators * }\end{array}$ \\
\hline Bassani et al. 23 & 2007 & $\begin{array}{c}\text { Not } \\
\text { declared }\end{array}$ & $\begin{array}{c}\text { Not } \\
\text { declared }\end{array}$ & 915 & $\begin{array}{l}\text { Case- } \\
\text { control }\end{array}$ & $\begin{array}{l}3+\text { sites, from different } \\
\text { teeth, presenting } 3+\mathrm{mm} \text { of } \\
\text { loss of attachment, having } \\
\text { the cement-enamel } \\
\text { junction as reference }\end{array}$ & $\begin{array}{l}\text { Color/race, schooling and } \\
\text { socioeconomic position }\end{array}$ \\
\hline Santos et al. 31 & 2007 & 10 & 18 & 765 & $\begin{array}{c}\text { Cross- } \\
\text { sectional }\end{array}$ & $\begin{array}{c}\% \text { of sextants with gingival } \\
\text { bleeding, presence of } \\
\text { calculus, and presence } \\
\text { of gingival recession/ } \\
\text { hyperplasia }\end{array}$ & Sex, type of school \\
\hline Nicolau et al. 38 & 2007 & 12 & 12 & 224 & $\begin{array}{l}\text { Cross- } \\
\text { sectional }\end{array}$ & $\begin{array}{c}>41 \% \text { of all teeth with } \\
\text { loss of attachment }\end{array}$ & $\begin{array}{c}\text { Income, paternal } \\
\text { schooling, respondent } \\
\text { schooling }\end{array}$ \\
\hline Antunes et al. 24 & 2006 & 12 & 12 & 5,780 & $\begin{array}{l}\text { Cross- } \\
\text { sectional }\end{array}$ & $\begin{array}{c}\mathrm{CPI}-\mathrm{CPI} \geq 1 \text { in } 1+ \\
\text { sextants, and } \mathrm{CPI}=2 \text { in } \\
1+\text { sextants }\end{array}$ & $\begin{array}{c}\text { Color/race, sex, type of } \\
\text { school }\end{array}$ \\
\hline Pion et al. 20 & 2006 & 10 & 76 & 588 & $\begin{array}{c}\text { Cross- } \\
\text { sectional }\end{array}$ & $\begin{array}{l}\text { Counts of teeth with } \\
\text { probing depth of } 3+\mathrm{mm}\end{array}$ & Sex \\
\hline Feldens et al. 32 & 2006 & 3 & 5 & 490 & $\begin{array}{l}\text { Cross- } \\
\text { sectional }\end{array}$ & $\begin{array}{c}\text { Ainamo \& Bay } 54 \text { gingival } \\
\text { bleeding index in } 1+\text { tooth } \\
\text { surfaces }\end{array}$ & $\begin{array}{l}\text { Income, maternal } \\
\text { schoolings, sex }\end{array}$ \\
\hline Hugo et al. 34 & 2006 & 50 & 86 & 230 & $\begin{array}{c}\text { Cross- } \\
\text { sectional }\end{array}$ & $\begin{array}{l}\text { Ainamo \& Bay }{ }^{54} \text { gingival } \\
\text { bleeding index, > the } \\
\text { population mean of teeth } \\
\text { with bleeding sextants }\end{array}$ & Income, schooling, sex \\
\hline Macedo et al. 30 & 2006 & 20 & 60 & 172 & $\begin{array}{l}\text { Cross- } \\
\text { sectional }\end{array}$ & $\begin{array}{l}4+\text { teeth with } 1 \text { or more } \\
\text { sites with probing depth } \\
\text { of } 4+\mathrm{mm} \text { and loss of } \\
\text { attachment of } 3+\mathrm{mm} \text { in } \\
\text { the same site }\end{array}$ & $\begin{array}{l}\text { Household crowding, } \\
\text { income, schooling, sex }\end{array}$ \\
\hline Susin \& Albandar 41 & 2005 & 14 & 29 & 612 & $\begin{array}{l}\text { Cross- } \\
\text { sectional }\end{array}$ & $\begin{array}{l}4+\text { teeth with loss of } \\
\text { attachment of } 4+\mathrm{mm} \text { or } \\
5+\mathrm{mm}\end{array}$ & $\begin{array}{c}\text { Color/race, sex, } \\
\text { socioeconomic position }\end{array}$ \\
\hline Susin et al. 45 & 2005 & 30 & 103 & 853 & $\begin{array}{l}\text { Cross- } \\
\text { sectional }\end{array}$ & $\begin{array}{l}1 \%-20 \% \text { of all teeth with } \\
\text { probing depth } 5+\mathrm{mm}, \\
>20 \% \text { with probing depth } \\
5+\mathrm{mm}\end{array}$ & $\begin{array}{c}\text { Color/race, sex, } \\
\text { socioeconomic position }\end{array}$ \\
\hline Susin et al. 42 & 2004 & 30 & 103 & 853 & $\begin{array}{l}\text { Cross- } \\
\text { sectional }\end{array}$ & $\begin{array}{l}15-50 \% \text { or }>50 \% \text { of } \\
\text { all teeth with loss of } \\
\text { attachment } 5+\mathrm{mm}\end{array}$ & $\begin{array}{c}\text { Color/race, sex, } \\
\text { socioeconomic position }\end{array}$ \\
\hline Susin et al. 43 & 2004 & 14 & $\begin{array}{c}\text { Not } \\
\text { declared }\end{array}$ & 843 & $\begin{array}{l}\text { Cross- } \\
\text { sectional }\end{array}$ & $\begin{array}{l}1-15 \% \text { of all teeth with } \\
\text { gingival recession of } \\
1+\mathrm{mm} \text { and } 3+\mathrm{mm}, 16+\% \\
\text { of all teeth with gingival } \\
\text { recession of } 1+\mathrm{mm} \text { and } \\
3+\mathrm{mm}\end{array}$ & $\begin{array}{c}\text { Color/race, sex, } \\
\text { socioeconomic position }\end{array}$ \\
\hline Susin et al. 44 & 2004 & 30 & 103 & 843 & $\begin{array}{l}\text { Cross- } \\
\text { sectional }\end{array}$ & $\begin{array}{c}>30 \% \text { of all teeth with loss } \\
\text { of attachment } 5+\mathrm{mm}\end{array}$ & $\begin{array}{c}\text { Color/race, sex, } \\
\text { socioeconomic position }\end{array}$ \\
\hline
\end{tabular}

(continues) 
Table 3 (continued)

\begin{tabular}{|c|c|c|c|c|c|c|c|}
\hline First author's surname & $\begin{array}{c}\text { Publication } \\
\text { year }\end{array}$ & $\begin{array}{l}\text { Minimum } \\
\text { age }\end{array}$ & $\begin{array}{l}\text { Maximum } \\
\text { age }\end{array}$ & $\begin{array}{l}\text { Sample } \\
\text { size }\end{array}$ & $\begin{array}{l}\text { Study } \\
\text { design }\end{array}$ & $\begin{array}{l}\text { Outcome } \\
\text { assessment }\end{array}$ & $\begin{array}{l}\text { Inequality } \\
\text { indicators * }\end{array}$ \\
\hline Segundo et al. 40 & 2004 & 13 & $\begin{array}{c}\text { Not } \\
\text { declared }\end{array}$ & 96 & $\begin{array}{l}\text { Cross- } \\
\text { sectional }\end{array}$ & $\begin{array}{l}\% \text { of all teeth with gingival } \\
\text { bleeding, attachment loss } \\
\text { of } 4+\mathrm{mm}, \% \text { of dental } \\
\text { surfaces with calculus, and } \\
\text { probing depth of } 4+\mathrm{mm}\end{array}$ & Schooling, sex \\
\hline Moraes 18 & 2003 & 3 & 5 & 518 & $\begin{array}{l}\text { Cross- } \\
\text { sectional }\end{array}$ & $\begin{array}{l}\text { Ainamo \& Bay }{ }^{54} \text { gingival } \\
\text { bleeding index - \% of } \\
\text { all dental surfaces with } \\
\text { gingival bleeding, } \\
\text { presence of teeth with } \\
\text { probing depth of } 2+\mathrm{mm}\end{array}$ & Sex \\
\hline Nicolau et al. 37 & 2003 & 13 & 13 & 311 & $\begin{array}{l}\text { Cross- } \\
\text { sectional }\end{array}$ & $\begin{array}{c}\mathrm{CPI} \text { - gingival bleeding in } \\
\quad>62 \% \text { of all teeth }\end{array}$ & $\begin{array}{l}\text { Bathroom in the } \\
\text { household, car ownership, } \\
\text { household ownership, } \\
\text { household crowding, } \\
\text { income, paternal } \\
\text { schooling, maternal } \\
\text { schooling, school retard, } \\
\text { piped water in the } \\
\text { household }\end{array}$ \\
\hline Cortelli et al. 29 & 2002 & 15 & 25 & 600 & $\begin{array}{l}\text { Cross- } \\
\text { sectional }\end{array}$ & $\begin{array}{l}\text { Incipient, localized and } \\
\text { generalized periodontitis }\end{array}$ & $\begin{array}{c}\text { Color/race, sex, } \\
\text { socioeconomic position }\end{array}$ \\
\hline Maltz et al. 35 & 2001 & 12 & 12 & 1,000 & $\begin{array}{l}\text { Cross- } \\
\text { sectional }\end{array}$ & $\begin{array}{c}\text { van der Weijde } 55 \text { gingival } \\
\text { bleeding index - \% of } \\
\text { bleeding surfaces }\end{array}$ & $\begin{array}{c}\text { Income, parental } \\
\text { schooling, type of school }\end{array}$ \\
\hline Gesser et al. 33 & 2001 & 18 & 18 & 286 & $\begin{array}{l}\text { Cross- } \\
\text { sectional }\end{array}$ & $\begin{array}{l}\text { Gingival bleeding in } 1+ \\
\text { sextants, calculus in } 1+ \\
\text { sextants, and pockets in } \\
1+\text { sextants }\end{array}$ & $\begin{array}{c}\text { Income, maternal } \\
\text { schooling, paternal } \\
\text { schooling, respondent } \\
\text { schooling }\end{array}$ \\
\hline Cangussu \& Coelho 22 & 2001 & 5 & 15 & 252 & $\begin{array}{l}\text { Cross- } \\
\text { sectional }\end{array}$ & $\begin{array}{l}\mathrm{CPI} \text { - counts of teeth with } \\
\text { gingival bleeding, calculus } \\
\text { and shallow pockets, \% of } \\
\text { healthy sextants }\end{array}$ & $\begin{array}{l}\text { Income, urban/rural } \\
\text { residence }\end{array}$ \\
\hline Ronderos et al. 21 & 2001 & 20 & 70 & 244 & $\begin{array}{l}\text { Cross- } \\
\text { sectional }\end{array}$ & $\begin{array}{l}\text { Periodontal attachment } \\
\text { loss in millimetres, probing } \\
\text { depth in millimetres, and } \\
\text { distance from gingival } \\
\text { margin to the cement- } \\
\text { enamel junction in } \\
\text { millimetres }\end{array}$ & Ethnicity, sex \\
\hline Machion et al. 36 & 2000 & 15 & $\begin{array}{c}\text { Not } \\
\text { declared }\end{array}$ & 100 & $\begin{array}{l}\text { Cross- } \\
\text { sectional }\end{array}$ & $\begin{array}{l}\text { WS system probing } \\
\text { depth } 56 \text { - counts of } \\
3+\mathrm{mm} \text { pockets }\end{array}$ & Sex \\
\hline Tomita et al. 19 & 1999 & 15 & $\begin{array}{c}\text { Not } \\
\text { declared }\end{array}$ & 156 & $\begin{array}{l}\text { Cross- } \\
\text { sectional }\end{array}$ & $\begin{array}{l}\mathrm{CPI}-\text { counts of teeth with } \\
\text { calculus, } 4-\mathrm{mm} \text { pockets, } \\
\text { and } 6+\mathrm{mm} \text { pockets }\end{array}$ & Income, sex \\
\hline
\end{tabular}

CPI: Community Periodontal Index.

* Socioeconomic position refers to an index combining information on household assets and participants' schooling. Such an index was used, for instance, in the study by Susin et al. 45 . 
Statistical significance and direction or shape of association between periodontal outcomes and indicators of inequality *. Brazil, $1999-2008$.

\begin{tabular}{|c|c|c|c|}
\hline Indicator of inequality & Direction or shape of association & $\%$ statistically significant $(p<0.05)$ & $\begin{array}{c}\text { Frequency with which this direction or } \\
\text { shape of association was observed }\end{array}$ \\
\hline \multirow[t]{3}{*}{ Schooling } & Negative & 60.0 & $10(83.4)$ \\
\hline & Positive & - & $1(8.3)$ \\
\hline & U shaped & - & $1(8.3)$ \\
\hline \multirow[t]{3}{*}{ Income } & Negative & 30.0 & $10(71.4)$ \\
\hline & Positive & - & $3(21.4)$ \\
\hline & Not described & - & $1(7.2)$ \\
\hline Race, ethnicity or & More frequent in Blacks and/or Browns & 80.0 & $5(38.5)$ \\
\hline \multirow[t]{3}{*}{ skin color } & More frequent in non-Blacks & 33.3 & $6(46.2)$ \\
\hline & No difference & - & $1(7.7)$ \\
\hline & Not described & - & $1(7.7)$ \\
\hline \multirow[t]{3}{*}{ Sex/gender } & Mor frequent in men & 45.8 & $24(77.4)$ \\
\hline & More frequent in women & 50.0 & $4(12.9)$ \\
\hline & Not described & - & $3(9.7)$ \\
\hline Socioeconomic position ** & Negative & 44.4 & $9(100.0)$ \\
\hline
\end{tabular}

* We show only those indicators of inequality that were cross-tabulated with periodontal outcomes at least nine times;

** Socioeconomic position refers to an index combining information on household assets and participants' schooling. Such an index was used, for instance, in the study by Susin et al. 45 .

policymakers. Among the strong aspects identified in the review, we stress the authors' emphases on the proper periodontal outcome definition and conceptualization, along with the wider use of diagnostic reliability measures. On the other hand, the lack of theoretical support of the relationship between periodontal outcomes, socioeconomic and demographic variables, the absence of parameters which guided sample size calculation, and the lack of mention about data quality control are the main limitations of the papers analyzed here. The use of insufficient sample sizes and inadequate sample selection procedures, for instance, may lead to selection bias and, consequently, preclude the study's results.

Corroborating with the periodontal epidemiological literature, we noticed a plethora of periodontal disease indicators used for the studies. Among those indexes used, we highlighted the CPI, which is recommended by the WHO in oral health surveys. However, this index has some limitations, such as the underestimation of the less severe periodontal conditions (for example, calculus and gingival bleeding) and underestimation of the outcome prevalence. These weaknesses are particularly relevant when etiological studies are taken into account 50 .

Schooling and income were the most used socioeconomic indicators in the articles re- viewed, a similar result found among Brazilian studies carried out in the 1990s which addressed social stratification in dental caries and epidemiological studies of periodontal outcomes 51 . Level of education is easily assessed; it is useful because it can be applied to both sexes, is applicable to persons not in the labour force, has stability over the adult lifespan, and is comparable between different regions. In addition, a higher education level is generally predictive of better jobs, higher incomes, better housing and socio-economic position 52 . Race, ethnicity or skin color has been investigated less as a "determinant" of periodontal outcomes. When this issue is addressed, the authors have not explained what race, ethnicity or skin color are proxies for, nor have they provided theoretical explanations about how race, ethnicity or skin color would act in their analytical models. It is very important to emphasize the absence of any social class indicator in the studies reviewed. Social class is difficult to use from a practical point of view and requires a deep theoretical basis. However, studies employing social class indicators may shed some light into other sources of variability in periodontal outcomes, which were not addressed by the studies reviewed.

Some comments about the limitations of this review are necessary. Firstly, we did not search for references in book chapters or text-books, nor 
did we consult Masters' Dissertations or Doctoral Theses. Experts in the field were not contacted in order to identify and obtain unpublished works or those which were not stored in the selected electronic data sources. Secondly, the review findings were not stratified according to different periodontal outcomes, i.e. gingivitis and periodontitis, which may be implicated in somewhat different etiological mechanisms. Moreover, our analysis of the associations between inequality indicators and periodontal outcomes did not take into account the magnitude of the effects and adjustment for confounding variables; reliance only on statistical significance may be misleading in some cases, especially those in which it derives from unadjusted analysis or the effect size is not relevant. Finally, this review was restricted to the period between 1999 and 2008, such that some of its conclusions may not be applicable to previous decades of periodontal research in Brazil.

In summary, we suggest that periodontal outcomes are more prevalent among social groups placed at the bottom of the social ladder, which may be interpreted as social inequalities in periodontal health. General policies towards a reduction of social inequalities should be considered in addition to specific periodontal oriented programs.

\section{Resumo}

O objetivo deste trabalho foi revisar a literatura epidemiológica brasileira sobre condições periodontais e aspectos sociodemográficos, avaliando características bibliográficas e metodológicas dessa produção, bem como a consistência e a significância estatística das associações examinadas. Foi conduzida uma revisão sistemática, por meio de consulta eletrônica, a seis fontes bibliográficas. A revisão foi restrita ao período de 1999 a 2008, sem a imposição de quaisquer outros limites de pesquisa. Entre os 410 artigos identificados, 29 foram incluídos na revisão. Observa-se crescimento da produção, especialmente no último quadriênio. Entretanto, há uma concentração dos estudos nas regióes Sul e Sudeste do país, e os trabalhos não se apoiam explicitamente em elaborações teóricas pertinentes ao tema. Apesar dessas limitações, os resultados dessa revisão sugerem que há uma relação inversa entre indicadores socioeconômicos e desfechos periodontais, demonstrada especialmente por indicadores de renda e escolaridade.

Doenças Periodontais; Desigualdades em Saúde; Revisão

\section{Contributors}

J. L. Bastos planned the study, performed the systematic review, analysis and interpretation of the data. A. F. Boing planned the study, performed the systematic review and helped interpret the data. K. G. Peres and J. L. F. Antunes contributed to the interpretation of the data. M. A. Peres planned the study and helped analyze and interpret the data.

\section{Acknowledgments}

This work was sponsored by MCT/CNPq/MS-SCTIEDECIT 26/2006 - Estudo de Determinantes Sociais da Saúde, Saúde da Pessoa com Deficiência, Saúde da População Negra, Saúde da População Masculina (grant $n^{\circ}$. 409630/2006-3). 


\section{References}

1. Petersen PE. The World Oral Health Report 2003: continuous improvement of oral health in the 21st century: the approach of the WHO Global Oral Health Programme. Community Dent Oral Epidemiol 2003; 31 Suppl 1:3-23.

2. Cascaes AM, Peres KG, Peres MA. Periodontal disease is associated with poor self-rated oral health among Brazilian adults. J Clin Periodontol 2009; 36:25-33.

3. Albandar JM, Rams TE. Risk factors for periodontitis in children and young persons. Periodontol 2000 2002; 29:207-22.

4. Kinane DF, Attstrom R. Advances in the pathogenesis of periodontitis. Group B consensus report of the fifth European Workshop in Periodontology. J Clin Periodontol 2005; 32 Suppl 6:130-1.

5. Albandar JM. Global risk factors and risk indicators for periodontal diseases. Periodontol 2000 2002; 29:177-206.

6. Currie C, Gabhainn S, Godeau E, Roberts C, Smith $\mathrm{R}$, Currie D, et al. Inequalities in young people's health: HBSC international report from the 2005/2006 survey. Edinburgh: University of Edinburgh; 2008.

7. Baelum V, Lopez R. Periodontal epidemiology: towards social science or molecular biology? Community Dent Oral Epidemiol 2004; 32:239-49.

8. Borrell LN, Burt BA, Neighbors HW, Taylor GW. Social factors and periodontitis in an older population. Am J Public Health 2004; 94:748-54.

9. Borrell LN, Crawford ND. Social disparities in periodontitis among United States adults 1999-2004. Community Dent Oral Epidemiol 2008; 36:383-91.

10. Klinge B, Norlund A. A socio-economic perspective on periodontal diseases: a systematic review. J Clin Periodontol 2005; 32 Suppl 6:314-25.

11. Dahlgren G, Whitehead M. European strategies for tackling social inequities in health: levelling up (part 2). Copenhagen: World Health Organization; 2006.

12. Lopez J, Perry G. Inequality in Latin America: determinants and consequences. Washington, DC: Office of the Regional Chief Economist, The World Bank; 2008. (Policy Research Working Paper 4504).

13. Lopes-Calva LF, Lusting N. The recent deline of inequality in Latin Ameriacn: Argentina, Brazil, Mexico and Peru: society for the study of economic inequality. Palma de Mallorca: Society for the Study of Economic Inequality; 2009. (Working Paper Series).

14. Victora CG. Prefácio. In: Antunes JLF, Peres MA, editors. Epidemiologia da saúde bucal. Rio de Janeiro: Editora Guanabara Koogan; 2006. p. 16

15. Downs SH, Black N. The feasibility of creating a checklist for the assessment of the methodological quality both of randomised and non-randomised studies of health care interventions. J Epidemiol Community Health 1998; 52:377-84.

16. Monteiro PO, Victora CG. Rapid growth in infancy and childhood and obesity in later life: a systematic review. Obes Rev 2005; 6:143-54.
17. Antunes JL, Peres MA, Frias AC, Crosato EM, Biazevic MG. Saúde gengival de adolescentes e a utilização de serviços odontológicos, Estado de São Paulo. Rev Saúde Pública 2008; 42:191-9.

18. Moraes ES, Valença AMG. Prevalência de gengivite e periodontite em crianças de 3 a 5 anos na cidade de Aracajú (SE). Ciênc Odontol Bras 2003; 6:87-94.

19. Tomita NE, Cordeiro R, Mendonça JS, Senger V, Lopes ES. Saúde bucal dos trabalhadores de uma indústria alimentícia do centro-oeste paulista. Rev Fac Odontol Bauru 1999:67-71.

20. Pion FLB, Araujo MWB, Feres M, Cortelli SC. Condição periodontal de um subgrupo populacional do município de Guarulhos, SP. Rev Bras Epidemiol 2006; 9:335-45.

21. Ronderos M, Pihlstrom BL, Hodges JS. Periodontal disease among indigenous people in the Amazon rain forest. J Clin Periodontol 2001; 28:995-1003.

22. Cangussu MCT, Coelho EO. Epidemiologia e iniqüidade em saúde bucal aos 5, 12 e 15 anos de idade, no município de Itatiba, São Paulo, 2000. Rev Fac Odontol Bauru 2001; 9:77-85.

23. Bassani DG, Olinto MTA, Kreiger N. Periodontal disease and perinatal outcomes: a case-control study. J Clin Periodontol 2007; 34:31-9.

24. Antunes JL, Peres MA, Jahn GM, Levy BB. The use of dental care facilities and oral health: a multilevel approach of schoolchildren in the Brazilian context. Oral Health Prev Dent 2006; 4:287-94.

25. Corraini P, Baelum V, Pannuti CM, Pustiglioni AN, Romito GA, Pustiglioni FE. Periodontal attachment loss in an untreated isolated population of Brazil. J Periodontol 2008; 79:610-20.

26. Coelho SR, Gusmao ES, Jovino-Silveira RC, Caldas Ade F. Profile of periodontal conditions in a Brazilian adult population. Oral Health Prev Dent 2008; 6:139-45.

27. Corraini P, Baelum V, Pannuti CM, Pustiglioni AN, Romito GA, Pustiglioni FE. Risk indicators for increased probing depth in an isolated population in Brazil. J Periodontol 2008; 79:1726-34.

28. Cortellazzi KL, Pereira SM, Tagliaferro EP, Ambrosano GM, Zanin L, Meneghim MC, et al. Risk indicators of gingivitis in 5-year-old Brazilian children. Oral Health Prev Dent 2008; 6:131-7.

29. Cortelli JR, Cortelli SC, Pallos D, Jorge AO. Prevalência de periodontite agressiva em adolescentes e adultos jovens do Vale do Paraíba. Pesqui Odontol Bras 2002; 16:163-8.

30. Macedo TC, Costa CM, Gomes-Filho IS, Vianna MI, Santos CT. Factors related to periodontal disease in a rural population. Braz Oral Res 2006; 20:257-62.

31. Santos NCN, Alves TDB, Freitas VS. A saúde bucal de adolescentes: aspectos de higiene, de cárie dentária e doença periodontal nas cidades de Recife, Pernambuco e Feira de Santana, Bahia. Ciên Saúde Coletiva 2007; 12:1155-66.

32. Feldens EG, Kramer PF, Feldens CA, Ferreira SH. Distribution of plaque and gingivitis and associated factors in 3- to 5-year-old Brazilian children. J Dent Child (Chic) 2006; 73:4-10. 
33. Gesser HC, Peres MA, Marcenes W. Condições gengivais e periodontais associadas a fatores socioeconômicos. Rev Saúde Pública 2001; 35:289-93.

34. Hugo FN, Hilgert JB, Bozzetti MC, Bandeira DR, Goncalves TR, Pawlowski J, et al. Chronic stress, depression, and cortisol levels as risk indicators of elevated plaque and gingivitis levels in individuals aged 50 years and older. J Periodontol 2006; 77:1008-14.

35. Maltz M, Barbachan-e-Silva B. Relação entre cárie, gengivite e fluorose e nível socioeconômico em escolares. Rev Saúde Pública 2001; 35:170-6.

36. Machion L, Freitas PM, Cesar Neto JB, Nogueira Filho GR, Nociti Jr. FH. A influência do sexo e da idade na prevalência de bolsas periodontais. Pesqui Odontol Bras 2000; 14:33-37.

37. Nicolau B, Marcenes W, Hardy R, Sheiham A. A life-course approach to assess the relationship between social and psychological circumstances and gingival status in adolescents. J Clin Periodontol 2003; 30:1038-45.

38. Nicolau B, Netuveli G, Kim JW, Sheiham A, Marcenes W. A life-course approach to assess psychosocial factors and periodontal disease. J Clin Periodontol 2007; 34:844-50.

39. Peres MA, Antunes JL, Boing AF, Peres KG, Bastos JL. Skin color is associated with periodontal disease in Brazilian adults: a population-based oral health survey. J Clin Periodontol 2007; 34:196-201.

40. Segundo TK, Ferreira EF, Costa JE. A doença periodontal na comunidade negra dos Arturo's, Contagem, Minas Gerais, Brasil. Cad Saúde Pública 2004; 20:596-603.

41. Susin C, Albandar JM. Aggressive periodontitis in an urban population in southern Brazil. J Periodontol 2005; 76:468-75.

42. Susin C, Dalla-Vecchia CF, Oppermann RV, Haugejorden O, Albandar JM. Periodontal attachment loss in an urban population of Brazilian adults: effect of demographic, behavioral, and environmental risk indicators. J Periodontol 2004; 75:1033-41.

43. Susin C, Haas AN, Oppermann RV, Haugejorden O, Albandar JM. Gingival recession: epidemiology and risk indicators in a representative urban Brazilian population. J Periodontol 2004; 75:1377-86.

44. Susin C, Oppermann RV, Haugejorden O, Albandar JM. Periodontal attachment loss attributable to cigarette smoking in an urban Brazilian population. J Clin Periodontol 2004; 31:951-8.

45. Susin C, Valle P, Oppermann RV, Haugejorden O, Albandar JM. Occurrence and risk indicators of increased probing depth in an adult Brazilian population. J Clin Periodontol 2005; 32:123-9.
46. Gil-Montoya JA, Navarrete-Cortes J, Pulgar R, Santa S, Moya-Anegon F. World dental research production: an ISI database approach (1999-2003). Eur J Oral Sci 2006; 114:102-8.

47. Guimarães J. A pesquisa médica e biomédica no Brasil: comparações com o desempenho científico brasileiro e mundial. Ciênc Saude Coletiva 2004; 9:303-27.

48. Zorzetto R, Razzouk D, Dubugras MT, Gerolin J, Schor N, Guimaraes JA, et al. The scientific production in health and biological sciences of the top 20 Brazilian universities. Braz J Med Biol Res 2006; 39:1513-20.

49. Rothman KJ, Greenland S. Modern epidemiology. Philadelphia: Lippincott-Raven; 1998.

50. Bassani DG, Silva CM, Oppermann RV. Validity of the Community Periodontal Index of Treatment Needs' (CPITN) for population periodontitis screening. Cad Saúde Pública 2006; 22:277-83.

51. Boing AF, Peres MA, Kovaleski DF, Zange SE, Antunes JL. Estratificação sócio-econômica em estudos epidemiológicos de cárie dentária e doenças periodontais: características da produção na década de 90. Cad Saúde Pública 2005; 21:673-8.

52. Lynch J, Kaplan G. Socioeconomic position. In: Berkman L, Kawachi I, editors. Social epidemiology. New York: Oxford University Press; 2000. p. 13-35

53. Amaral CS, Luiz RR, Leão ATT. The relationship between alcohol dependence and periodontal disease. J Periodontal 2008; 79:993-8.

54. Ainamo J, Bay I. Problems and proposals for recording gingivitis and plaque. Int Dent J 1975; 25:229-35.

55. van der Weijden GA, Timmerman MF, Nijboer A, Reijerse E, van Der Vekden V. Comparison of different approaches to asses bleeding on probing as indicators of gingivitis. J Clin Periodontal 1994; 21:589-94.

56. Sallum AW, Sallum EA. Indicação e seqüência em cirurgia periodontal. In: Todescan F, Bottino M, editors. Atualização na clínica odontológica: a prática da clinica geral. São Paulo: Editora Artes Médicas; 1996. p. 585-90.

Submitted on $18 /$ Jun $/ 2010$

Final version resubmitted on 30/Nov/2010

Approved on 20/Dec/2010 